\title{
The Impact of Critical Thinking Disposition on Learning using Business Simulations
}

\author{
Robin Bell \& Mark Loon \\ (r.bell@worc.ac.uk) \\ International Journal of Management Education (2015), Vol. 13, No. 2, pp. 119-127. \\ http://dx.doi.org/10.1016/j.ijme.2015.01.002
}

\begin{abstract}
This research seeks to determine the relationship between students' critical thinking disposition and their learning while engaging in a business simulation at a UK higher education institution (HEI). The research informs educators making decisions about the use of simulations as to the value of considering critical thinking dispositions. Previous research has found that simulations are an effective way for students to engage actively in learning, bridging the gap between theory and practice. It has also been found that such simulations can develop students' critical thinking skills. However, hitherto no research has been undertaken into the role that existing critical thinking disposition has on the learning of students, as measured by the degree to which students perceived that they met the module's intended learning outcomes. This research offers insights into the role and importance of critical thinking disposition and its component dimensions and how this impacts student learning. The results indicate that the level of critical thinking disposition is positively related to the students' learning. The implications of the research suggest educators should target business simulations at specific cohorts of students. The relative importance of the critical thinking disposition constructs and the practical educational implications of these findings are discussed.
\end{abstract}

\section{Keywords}

Business Simulation, Critical Thinking, Critical Thinking Dispositions. 


\section{Critical Thinking Skills and Critical Thinking Disposition}

The term critical thinking is widely used in the fields of education, psychology, and philosophy, and there have been repeated attempts to define the concept in order to increase the understanding of how this cognitive ability can be utilised (Friedel et al., 2008).

An early definition by Dewey (1933, p.118) described critical thinking as "active persistent and careful consideration of a belief or supposed form of knowledge in light of the grounds that support it, and the further conclusions to which it tends." More recently, critical thinking has been defined as being the "purposeful, self-regulatory judgement, which results in interpretation, analysis, and inference, as well as explanation of the evidential, conceptual, methodological, criteriological, or contextual considerations upon which that judgement is based" (Facione, 1990 p2). Halpern (1996, p. 5) defined critical thinking as "thinking that is purposeful, reasoned and goal directed - the kind of thinking involved in solving problems, formulating inferences, calculating likelihood, and making decisions." Critical thinking is essential as a tool of enquiry (Faccione, 1990) and has been argued to be underemphasized at the business school level (Örtenbald et al., 2013). It is believed to be vital for individuals to achieve their full potential (Meyers 1986) and to be one of the most valuable attributes for success in the twenty-first century (Huitt, 1998).

Critical thinking skills, however, are not stand-alone abilities. An individual requires the appropriate critical thinking disposition to use those skills (Friedel et al., 2008; Tishman et al., 1993). A critical thinking disposition can be defined as the consistent internal motivation to engage problems and make decisions through the use of critical thinking (Facione et al., 1996) and is a measure of the tendency towards critical thinking (Stedman and Andenoro, 2007).

Critical-thinking dispositions are attitudinal and can be developed, although their development may take longer than the development of critical thinking skills. Approaches that develop critical thinking skills can also improve critical thinking disposition (Tishman and Andrade, 1996). Research has suggested that, being inherently linked, both critical thinking skills and disposition should be developed together (Kitchener and King 1994). This was supported by Facione et al. (1995), who argued that, as skills and dispositions are mutually reinforced, they should be modelled and taught together. Importantly, critical thinking dispositions are precursors and gateways to critical thinking activity. A lower disposition is less likely to result in meaningful critical thinking that leads to problem solving, solutions, and decision making, whilst a higher disposition would be more likely to lead to these outcomes (Irani et al., 2007). 
Two frequently adopted measurement instruments for critical thinking dispositions are the California Critical Thinking Disposition Inventory (CCTI) (Facione, 2001), and the University of Florida Engagement, Cognitive Maturity and Innovativeness assessment (UF-EMI) (Irani et al., 2007), which was developed from the former.

The UF-EMI instrument has been used to investigate critical thinking disposition across a wide range of academic study, including emotional intelligence (Stedman and Andenoro, 2007), the development of study programs (Lamm et al., 2011), and problem solving (Friedel et al., 2008). It will be adopted in this research and consists of 26 items based on three constructs, namely, engagement, cognitive maturity, and innovativeness. The three dimensions (constructs) of critical thinking disposition are described (Irani et al., 2007; Ricketts and Rudd, 2004) below.

Engagement is the predisposition to look for and anticipate situations that require reasoning, the use of reasoning skills, and confidence in one's belief to reason, solve problems, and make decisions. Engagement results in a desire to use reasoning and communicate the reasoning process used to come to a decision (Irani et al., 2007).

Cognitive maturity is the predisposition to be aware of the complexity of problems, open to the viewpoints of others, aware of predispositions and biases of one self and others, and to consider these factors objectively before making decisions. Cognitive maturity results in an acceptance that problems are often more complex than they may first seem and as such there may be more than one appropriate solution.

Innovativeness is the predisposition to seek out new knowledge, be intellectually curious, and seek out the truth. Individuals displaying innovativeness want to know more about their profession, their life and the world around them, even if this is at odds with their own beliefs and opinions. They are constantly seeking new knowledge (Irani et al., 2007; Ricketts and Rudd, 2004).

\section{Business Simulations in Higher Education}

The development of critical thinking skills is high on the agenda for HE establishments (Stassen et al., 2011; Roth 2010: Kovalik and Kovalik, 2007; Halpern, 1998), and educators' teaching methods need to be adapted carefully to build on the students' current critical thinking skills in order to develop them 
further. Educators increasingly use virtual learning environments as a way to communicate effectively with students. Morris and Chikwa (2013) found that students who utilized e-learning to supplement their classroom-based studies experienced increased academic performance. The use of computer simulations provides an e-learning medium for active engagement and the utilization of critical thinking skills in a risk-free environment. Business simulation games are a form of computer simulation that have become increasingly popular for business studies in higher education establishments, enabling educators to provide a bridge between theory and practice via active engagement.

Computer-based simulations aim to provide an operating representation of the central features of reality (Guetzkow, 1963) by imitating a system, entity, process, or phenomenon (Lean et al., 2006). The use of simulations as an educational tool has grown considerably over the last forty years. Encouraged by the widespread availability of computers and the Internet, they have become an important part in business education (Faria et al., 2009). Increases in computer power, availability, and graphic capability have all played a part in this rapid development (Kirriemuir, 2002; Neps et al., 1997) and the increase in the sophistication of computer technology has now enabled the simulation of realistic situations in computer programs (Martin and McEvoy, 2003).

A business computer simulation is, in essence, a model or software program that requires participants to make business decisions. The most popular business computer simulations used in business and management education are gaming simulations (Adobor and Daneshfar, 2006). Computer simulations have been classified in several ways, including on the basis of their use, e.g., gaming, training and modelling (Lean et al., 2002) or on the underlying model of the simulation, i.e., discrete, continuous, or combined event (Feinstein et al., 2002).

Simulations can play a role in two areas of development. Firstly, they can provide a teaching framework in which participants make decisions to achieve their final goal, taking into consideration how the other participants' decisions will affect their own choices (Lainema and Nurmi, 2006). An individual's cognitive style, referring to the different but consistent way in which an individual perceives, thinks, solves problems, and relates to others (Witkin et al., 1977; Armstrong and Hird, 2009), has been shown to have in impact on decision styles (Taggart et al., 1985) and task orientations (Foxall et al., 1990). In addition, it has been argued that cognitive style influences adaptive behaviour and level of risk taking and conflict (Kirton, 1984). 
Secondly, the simulation process can reinforce learning through feedback after the results are obtained and the students' decisions discussed, allowing participants to reflect on and improve their strategies after the simulation experience (Arellano et al., 2001). The first area provides a simulation bridge between theory and practice, which allows students the opportunity to gain experience through engagement and learning through the actions they take and their consequences. The second area provides an opportunity for reflection and the development of reasoning and critical thinking skills.

Approximately one third of matriculated undergraduate business school students have experienced a simulation as part of their learning experience (Jackson, 2014). The reported benefits of business simulations include increased motivation (Fripp, 1997), experiential learning (Adobor and Daneshfar, 2006; Feinstein et al., 2002), integration of diverse student populations (Piercy and Caldwell, 2011) the development of critical thinking skills (Springer and Borthick, 2004; Martin and McEvoy, 2003; Doyle and Brown, 2000), a risk free environment (Fripp, 1997), a simplified real world (Doyle and Brown, 2000), the development of team working skills (King and Newman, 2009), and the acquisition of time management skills (Doyle and Brown, 2000). Business simulations allow students to make strategic decisions based on their theoretical knowledge in a safe environment (Adobor and Daneshfar, 2006). Despite a wide consensus over what pedagogic advantages simulations can provide (e.g. Faria \& Wellington, 2004; Lean et al., 2006), research into the barriers to the introduction of gaming simulations into business schools has highlighted a number of concerns expressed by educators. These include the resources required (both in capital expenditure and ongoing administrative and technical costs), a lack of fit with courses being taught, a lack of information regarding simulations, a preference for alternative pedagogic approaches, and the amount of class time required (Faria and Wellington, 2004).

The reported shortcomings of computer business simulations include the lack of suitability for gaining theoretical knowledge (Whiteley and Faria, 1989), the requirement for other traditional teaching required in combination (Doyle and Brown, 2000), the risk that an oversimplified or unrealistic simulation may result in some participants 'switching off' (Adobor and Daneshfar, 2006; Curry and Moutinho, 1992), team conflict and freeloading of some participants (Adobor and Daneshfar, 2006; Jehn and Mannix ,2001), a lack of flexibility (Morgan 2009), and a lack of effectiveness in general (Anderson and Lawton, 2009).

While some argue that the potential complexity of computer-based simulations could be a shortcoming (Anderson and Lawton, 2009; Lean et al., 2006), students are increasingly comfortable with many 
aspects of e-learning systems. E-learning systems in general are now a common part of the higher education experience and often viewed positively by students, which results in increasing use (Ituma, 2011; Ogba, Saul and Coated, 2011). In addition, Pryjmachuk et al. (2012) have shown that introducing students to e-learning via study skills courses can increase student comfort with the concept, leading to fewer obstacles to including computer simulations as part of study.

\section{Simulations and Intended Learning Outcomes}

Intended learning outcomes (ILOs) predict what students will gain as a result of successful learning. The importance of ensuring that simulations are aligned with the achievement of ILOs is highlighted widely in the literature (Moizer et al., 2009, Ellington, 2004; Feinstein et al., 2002). Feinstein et al. (2002) concludes that computer simulations are "not an educational panacea", and the choice of teaching format should be chosen with the teaching objectives and learning outcomes in mind. The literature further stresses that consideration should be paid to the suitability, maturity, and experience of the student cohort for whom the simulation is being considered (Moizer et al., 2009; Sutcliffe, 2002). Considerations may include: computer skills required for the simulation, the background theoretical knowledge required to complete the simulation, and the complexity of the simulation. Greater complexity may enable a more realistic simulation, but it may also reduce the ability of students to learn if they are overwhelmed by it (Moizer et al., 2009; Dempsey et al., 2002). Control-value theory suggests that students will be more motivated to engage with a learning activity if they perceive it as an appropriate challenge for their skill level, such that they have some level of control over the outcome of the activity (Cordova and Lepper, 1996; Pekrun et al., 2010).

Overall, business simulations can provide a valuable tool to supplement the more traditional methods of teaching (Avramenko, 2012; Anderson and Lawton, 2009; Lean et al., 2006; Doyle and Brown, 2000). They provide the opportunity to develop higher order thinking skills (Springer and Borthwick, 2004) through the development of critical and strategic thinking skills (Doyle and Brown, 2000; Lane, 1995) and generate insights in a risk free environment (Fripp, 1997). As such, they can be particularly useful for integrative courses (Moizer et al., 2009; Sutcliffe, 2002) and for teaching general management skills (Adobor and Daneshfar, 2006). 
This research will use the UF-EMI instrument to investigate the impact of the critical thinking disposition of individual students on the benefits to learning obtained from the simulation as measured by the degree to which the ILOs were met.

\section{Research Questions}

This research aims to determine whether learning through business simulations is affected by students' critical thinking disposition. Existing literature has highlighted the fact that educators should consider the experience and knowledge of their students and the complexity of the activity when using simulations to achieve ILOs. This research will examine whether educators when making decisions regarding the use of simulations should also consider critical thinking dispositions. The research will measure learning by the degree to which students perceived that they met the ILOs of the module. If the success of business simulations in meeting the ILOs is independent of critical thinking disposition, it is likely that business simulations can be used successfully across a wide range of students. Conversely, if those students with lower critical thinking disposition less successfully meet the ILOs, then it may be more important and appropriate to target specific business simulations at specific cohorts of students. In addition, this research will seek to investigate the relative importance of the constructs within the critical thinking disposition measurement instrument, namely engagement, cognitive maturity and innovativeness, on the perceptions of the students in meeting the ILOs.

The research questions that this research seeks to answer are as follows:

What is the impact of students' critical thinking dispositions on student learning during business simulations?

What is the relative importance of the individual critical thinking disposition dimensions in students' success in meeting ILOs?

From the above research question, the following hypothesis has been produced.

H1. Business students with greater critical thinking dispositions achieve better learning outcomes from business simulations. 


\section{Methodology}

The sample consisted of 173 final year students who undertook a change management simulation as part of a module entitled 'Enhancing Organizations' at a British higher education institute (HEI). The module was run within the university's business school and all the students enrolled were undertaking a business-related major. Adopting a sampling frame consisting of students within one department, at the same level and year of study, and at the same $\mathrm{HEl}$, should help to minimize the potential for wide variations in student motivation and academic abilities. The students were taught in five classes with the support of one instructor. Teams of approximately four students were required to introduce changes into the operations of the simulated organization to make and design products which were more green and environmentally friendly and to address environmental waste issues. Success was measured by each group's ability to achieve the greatest number of adopters of the change agenda within the organization, using the fewest resources to do so. Learning was based on action during the simulation and reflection on action after the simulation period. The simulation was undertaken across two weekly three hour sessions, each of which was followed by an instructor-led three hour reflective debrief. Structured approaches to the reflective stages can enhance the active interpretation of experience (Platzer et al 1997; Mezirow, 1990). Reflective debriefing is the point at which students analyze and uncover what they have learned through the simulation and thus is a crucial part of the learning process for students (Arellano et al., 2001; Cannice, 2014).

Data was collected through a self-administered Likert-style questionnaire that was distributed to all students upon completion of the simulation. Respondents were encouraged to consider the full range of the answer scales when completing the questionnaire, both verbally and within the printed instructions on the front page of the questionnaire. Completion of the forty-question questionnaire was voluntary and a total of 173 completed questionnaires were returned, representing a questionnaire completion rate of 65.8 percent. The questionnaire consisted of three parts: the respondents' demographics, an assessment of the degree to which the respondents perceive they met the ILOs through the simulation, and questions designed to measure the respondents' critical thinking disposition.

\section{Measurement Scales}

The respondents' critical thinking disposition was measured by the UF-EMI instrument (Irani et al., 2007), developed to measure the critical thinking disposition of students. The measurement instrument contains eleven questions to measure the engagement construct, eight questions to measure the 
cognitive maturity construct, and seven questions to measure the innovativeness construct. The overall critical thinking disposition score can then be calculated by summing the three construct scores, or the individual constructs can be tested (Irani et al., 2007; Ricketts and Rudd, 2004). This measurement instrument was selected as it has been used widely in higher education populations (e.g. Friedel et al., 2008; Lamm et al., 2011; Stedman and Andenoro, 2007; Ricketts and Rudd, 2004), and has previously been determined as reliable and valid (Lamm et al., 2011; Stedman and Andenoro, 2007; Ricketts and Rudd, 2004).

The business simulation was designed to bridge the gap between management theory and practice, while simultaneously developing their critical thinking and reasoning skills. The ILOs for the simulation are based on this intent. The students were asked on a scale of 1-5 how much they thought, 'The simulation has enabled me to' achieve each of the ILOs. The six ILO outcome questions for the simulation can be found in Table One.

Table 1 Questions to Measure the Intended Learning Outcomes of the Business Simulation

Questions to Measure the Intended Learning Outcomes

The simulation has enabled me to:

1. Practice my diagnostic skills in regards to leading strategic change.

2. Practice my action planning skills in regards to leading strategic change.

3. Gain insight into why individuals and groups might resist change and how to overcome that resistance.

4. Develop an appreciation for key contextual factors when implementing change.

5. Improve my ability to develop and apply appropriate change strategies and/ or tactics

6. Identify actions of successful/effective organisational change agents

\section{Data Analysis and Results}

In the first stage of the data analysis, the critical thinking disposition data produced from the UF-EMI measurement instrument was subjected to principle component analysis. This was conducted in order to help validate the measurement instruments in the field of UK higher education.

A principal component analysis with Varimax rotation was conducted on the data collected. In order to obtain clear factor structures, only items with a minimum loading of .4 were retained. From this, factor scores were then created around the emergent factors encompassing the latent variables for each of the critical thinking disposition dimensions identified. 
The emergent critical thinking disposition dimension factor scores were then added together to create the overall critical thinking disposition score for each participant. The responses to the questions measuring the six ILOs were also added together to create an overall ILO score.

Finally, the overall critical thinking disposition score and the individual critical thinking disposition dimension score were correlated and regressed against the overall ILO score to test whether the overall critical thinking score and the individual critical thinking disposition scores could predict the ILO score.

\section{Factor Analysis of Critical Thinking Disposition}

A KMO test was conducted and produced a measure of .853 , confirming that the data sample was suitable for principle component analysis ${ }^{1}$. Scale purification and item reduction, which was based on the removal of items demonstrating factor loadings below .4, produced (through the principle component analysis process) three subscales based on 25 items with significant factor loadings (see Table Two and Three). All of the original UF-EMI questions were correlated at the .4 level except 'I keep on working on things until I get them right.'

Table 2 Total Variance Explained in Principle Component Analysis of Scale Items Measuring Independent Variables

\begin{tabular}{|c|c|c|c|c|c|c|}
\hline \multirow[b]{2}{*}{ Factor } & \multicolumn{3}{|c|}{ Initial Eigenvalues } & \multicolumn{3}{|c|}{ Rotation Sums of Squared Loadings } \\
\hline & Total & $\%$ of Variance & Cumulative \% & Total & $\%$ of Variance & Cumulative \% \\
\hline 1 & 7.526 & 28.947 & 28.947 & 4.590 & 17.655 & 17.655 \\
\hline 2 & 2.218 & 8.532 & 37.479 & 3.655 & 14.056 & 31.711 \\
\hline 3 & 1.497 & 5.756 & 43.236 & 2.996 & 11.525 & 43.236 \\
\hline
\end{tabular}

Extraction method: Principle component

The three-factor structure accounted for 43.24 percent of the variance. The resultant emergent factors (dimensions) Engagement (28.95 percent), Cognitive Maturity (8.53 percent) and Innovation (5.76 percent) were in line with the work of Irani et al. (2007), which helped to demonstrate validity of the measurement instrument in the UK higher education setting.

The Cronbach Alpha score measures the internal consistency of the answers given to scale questions and provides evidence for the reliability of the scales. The scores for each individual factor that emerged from the principle component analysis are contained within Table Three. All of the dimensions exhibit a

\footnotetext{
${ }^{1}$ Kaiser (1974) recommended a bare minimum of .5, with values between .5 and .7 being mediocre, values between .7 and .8 being good and values between .8 and .9 are very good (Hutcheson and Sofroniou, 1999).
} 
Cronbach Alpha score greater than .7, indicating that the internal consistency for all of the factors to be tested is acceptable ${ }^{2}$.

The rotated factor structure for the critical thinking dispositions is presented in Table Three.

\footnotetext{
${ }^{2}$ Cronbach Alpha scores of greater than 0.7 are generally regarded as satisfactory in terms of internal validity (Bland and Altman, 1997). According to Sekaran (2003), reliabilities less than 0.6 are considered poor, those in the 0.7 range acceptable, and those over 0.8 good.
} 


\section{Table 3 Rotated Factor Matrix}

\begin{tabular}{|c|c|c|c|c|}
\hline \multirow[b]{2}{*}{ Dimensions } & \multirow[b]{2}{*}{ Item Description } & \multicolumn{3}{|l|}{ Factor } \\
\hline & & 1 & 2 & 3 \\
\hline \multirow{11}{*}{$\begin{array}{l}\text { Engagement } \\
\alpha=.859\end{array}$} & I am a good problem solver & .758 & & \\
\hline & I am confident that I can reach a reasonable conclusion & .709 & & \\
\hline & I am able to relate to a wide variety of issues & 677 & & \\
\hline & I am able to explain things clearly & .668 & & \\
\hline & I am able to apply my knowledge to a wide variety of issues & .668 & & \\
\hline & I present issues in a clear and precise manner & .616 & & \\
\hline & I enjoy finding answers to challenging questions & .567 & & \\
\hline & I am interested in many issues & .496 & & \\
\hline & I look for opportunities to solve problems & .459 & & \\
\hline & I ask focused questions when trying to clarify a solution & .427 & & \\
\hline & It is important to be well informed & .412 & & \\
\hline \multirow{8}{*}{$\begin{array}{l}\text { Cognitive } \\
\text { Maturity } \\
\alpha=.779\end{array}$} & $\begin{array}{l}\text { I listen carefully to the opinions of others even when they } \\
\text { disagree with me }\end{array}$ & & .770 & \\
\hline & I believe that most problems have more than one solution & & .599 & \\
\hline & I ask many questions when making a decision & & .591 & \\
\hline & I consider how my own biases affect my opinions & & .586 & \\
\hline & $\begin{array}{l}\text { I try to consider the facts without letting my biases affect my } \\
\text { decisions }\end{array}$ & & .561 & \\
\hline & I try to find multiple solutions to problems & & .551 & \\
\hline & I can get along with people who do not share my opinions & & .543 & \\
\hline & $\begin{array}{l}\text { I am likely to change my opinion when I am given new } \\
\text { information that conflicts with my current opinion }\end{array}$ & & .496 & \\
\hline \multirow{6}{*}{$\begin{array}{l}\text { Innovation } \\
\alpha=.731\end{array}$} & I enjoy learning about many topics & & & .691 \\
\hline & I will go out of my way to find the right answers to a problem & & & .616 \\
\hline & I search for the truth even when it makes me uncomfortable & & & .585 \\
\hline & I ask lots of questions in a learning environment & & & .553 \\
\hline & I enjoy learning even when I am not in University & & & .505 \\
\hline & I enjoy solving problems & & & .491 \\
\hline
\end{tabular}




\section{Regression and Correlation Analysis}

The Impact of Overall Critical Thinking Disposition

Correlation analysis between the overall critical thinking disposition score developed and the ILO score was undertaken. The analysis indicated there was a significant correlation between the two variables at a 99 percent confidence level. Regression analysis was then undertaken between the two variables, the results of which can be found in Table Four.

Table 4 Regression Model Predicting Learning Outcome from the Overall Critical Thinking Disposition Score

\begin{tabular}{lllll} 
& $\mathrm{SE}$ & Beta & $\mathrm{t}$ & Sig. \\
\hline Overall Critical Thinking Disposition & .038 & .506 & 7.663 & $.000^{*}$ \\
\hline * Significant at a 95\% Confidence Level & $\mathrm{R}^{2}=.256$ & & &
\end{tabular}

The results indicate that there was a significant positive relationship between the overall critical thinking disposition of the respondents and their ILO score at a 95 percent confidence level. The overall critical thinking disposition score is able to explain 25.6 percent $\left(R^{2}\right)$ of the variance within the ILO score.

\section{The Impact of the Individual Critical Thinking Dimensions}

Further analysis was undertaken to determine which dimensions within the critical thinking disposition were most influential in predicting the ILO score. Correlation analysis was undertaken between the individual critical thinking disposition dimensions to determine if any of the individual dimensions were significantly correlated to the ILO score. It was determined that that both the Engagement Factor Score and the Cognitive Maturity Factor Scores were correlated with the ILO score at a 99 percent confidence level (see table 5). Accordingly, these two dimensions were taken forward for regression analysis. The Innovation dimension was found not to be statistically correlated with the ILO score at a 99 or 95 percent confidence level. 
Table 5 Correlations Statistics between the Individual Component Factor Scores

\begin{tabular}{|c|c|c|c|c|}
\hline & $\begin{array}{l}\text { Engagement } \\
\text { Factor Score }\end{array}$ & $\begin{array}{l}\text { Cognitive Maturity } \\
\text { Factor Score }\end{array}$ & $\begin{array}{l}\text { Innovation } \\
\text { Factor Score }\end{array}$ & $\begin{array}{l}\text { Learning Outcomes } \\
\text { Factor Score }\end{array}$ \\
\hline $\begin{array}{l}\text { Engagement Factor } \\
\text { Score }\end{array}$ & - & & & \\
\hline $\begin{array}{l}\text { Cognitive Maturity } \\
\text { Factor Score }\end{array}$ & .000 & - & & \\
\hline $\begin{array}{l}\text { Innovation Factor } \\
\text { Score }\end{array}$ & .000 & .000 & - & \\
\hline $\begin{array}{l}\text { Learning Outcomes } \\
\text { Factor Score }\end{array}$ & $.435^{* *}$ & $.292^{* *}$ & .149 & - \\
\hline
\end{tabular}

** Correlation is significant at the .01 level ( 2 tailed)

* Correlation is significant at the .05 level ( 2 tailed

Stepwise regression analysis using the Engagement Factor Score and the Cognitive Maturity Factor Scores as independent variables and the ILO score as the dependent variable produced two models as shown in Table 6.

Table 6 Regression Models Predicting Learning Outcome from the Individual Component Factor Scores

\begin{tabular}{lcccc} 
& SE & Beta & $\mathrm{t}$ & Sig. \\
\hline Model 1 & & & & \\
Engagement Factor Score & .069 & .435 & 6.315 & $.000^{*}$ \\
\hline Model 2 & & & & \\
Engagement Factor Score & .065 & .435 & 6.655 & $.000^{*}$ \\
Cognitive Maturity Factor Score & .065 & .292 & 4.467 & $.000^{*}$ \\
\hline
\end{tabular}

The results indicate that an increase in both the Engagement and the Cognitive Maturity dimensions are able to predict an increase in the ILO score. The Engagement dimension has the biggest impact on the ILO score, explaining 18.9 percent $\left(R^{2}\right)$ of the variance in the ILO score. The Cognitive Maturity dimension supports this dimension and together they are able to explain 27.4 percent $\left(R^{2}\right)$ of the variance in the ILO score.

\section{Discussion and Conclusion}

The results of this research indicate that an increase in the critical thinking disposition, as measured by the UF-EMI measure instrument, was able to predict an increase in the ILO score. The results support the hypothesis that students with greater critical thinking dispositions achieve better learning outcomes 
from business simulations. It is widely acknowledged that the content of the simulation should be suitable for the student cohort in terms of experience, knowledge, and complexity (Moizer et al 2009, Sutcliffe, 2002), for the students to benefit the most from the simulation and achieve the required ILOs. This research suggests that critical thinking disposition should also be considered. The existing literature suggests that critical thinking skills can be developed and that business simulations can play a part in developing these skills (Springer and Borthick, 2004; Martin and McEvoy, 2003; Doyle and Brown, 2000). It is also widely accepted that, in developing critical thinking skills, critical thinking disposition can be improved, although the process may take longer (Tishman and Andrade, 1996). Indeed, it has been argued that critical thinking disposition is reinforced with the development of critical thinking skills (Facione et al., 1995). This argument suggests that the progressive use of simulations at an appropriate level (where students have a sufficient level of existing knowledge and critical thinking skills) may help to further develop not only the critical thinking skills of students further but, over time, may also develop their critical thinking dispositions.

Upon analysis, it was found that the Engagement dimension was the most influential critical thinking disposition dimension in students' level of success at achieving the ILOs. Engagement is the disposition to use reasoning skills, solve problems, make decisions and communicate the rational thereto (Irani et al., 2007). The study's finding suggests that individuals who already exhibit good reasoning, problem solving, and decision making skills are in a better position to meet the ILOs from simulations.

The Engagement dimension was statistically supported by the Cognitive Maturity dimension in predicting an increase the ILO score. Cognitive maturity is the disposition to be aware of the complexity of problems, to be open to the viewpoints of others, to be aware of internal and external predispositions and biases, and to consider biases objectively before making decisions (Irani et al, 2007). The results of this research suggest that those students who are more open minded to the opinions and views of others and have a greater awareness of the complexity of problem solving are better able to learn from simulations.

These two findings highlight the importance and value of the discussion, evaluation, and feedback stages to the simulation process. Engagement and Cognitive Maturity can be actively encouraged through discussion, the exchange of viewpoints, analysis, a review of decision making, and reflection on how things could have been done better. All participants should be actively encouraged to take part, listen, contribute, and reflect. Research suggests that making sense of situations can be enhanced by 
structured approaches to reflection (Platzer et al., 1997), giving individuals the opportunities to challenge existing beliefs and mind-sets and to come to a better understanding of what has taken place (Mezirow, 1990). Encouragement of the development of these two dimensions will have a beneficial effect on the development of the critical thinking disposition.

The Innovation dimension was not found to be statistically related to the ILO scores achieved in this research. Innovativeness was defined as the disposition to be intellectually curious and to seek new knowledge (Irani et al., 2007). Although innovation may play a part in critical thinking disposition, no association could be identified with the ILOs score in this research. The finding may be a result of innovation's focus on seeking out new knowledge, whereas, during the simulation, the required knowledge and information is given to students, and much of the learning benefit comes from the discussions, feedback and reflection at the end of the process. In short, this finding may be influenced by the specific requirements or demands that the simulation used in this research made on the individual students. Further research using different simulations may shed further light on this aspect.

It has been highlighted that the benefits from simulations can be maximized by discussions, analysis, feedback and revisiting the decision making process (Arellano et al., 2001), all of which could be considered to improve the depth of learning. These processes may well encourage and further develop critical thinking disposition and the component dimensions over time.

\section{Limitations and Future Research}

In common with all research, this project has limitations. The data collected for this project was based on a sample size of 173 participants undertaking one simulation exercise; however, the participants involved in the study had not previously undertaken a business simulation while studying their current degree program. Consequently, the participants all had equal exposure to business simulations and had similar levels of knowledge and experience of simulations while completing the simulation and questionnaire. Similarly, whilst the research only considered one-year group, the homogeneity of the group should ensure similar levels of business knowledge and university experience. Future research could be directed towards conducting similar research with larger sample sizes across different year groups to investigate the variation that the year and level of study might have on student learning during business simulations. It could be argued that the students' self-assessment of how the simulation met the ILOs may be less accurate than a formative or summative assessment result; however, such approaches have deficiencies which include the impact of potential external and unforeseen factors, 
whilst self-assessment allows individual respondents to take these potential factors into account when making their assessment. An interesting line of enquiry would be to test the critical thinking disposition of participants longitudinally over time after the same group of participants had undertaken a series of business simulations. Past research suggests that approaches to develop critical thinking skills (such as simulations) can also improve critical thinking disposition (Tishman and Andrade, 1996), and that critical thinking disposition is mutually reinforced along with the development of critical thinking skills (Facione et al., 1995). A study of this kind would not only provide evidence of this mutual reinforcement but would also provide useful information about the value of simulation formats. 


\section{References}

Adobor $\mathrm{H}$ and Daneshfar A (2006) Management simulations: Determining their effectiveness. Journal of Management Development 25(2): 151-168.

Armstrong SJ and Hird A (2009) Cognitive Style and Entrepreneurial Drive of New and Mature Business Owner-Managers. Journal of Business \& Psychology 24: 429-430.

Anderson PH and Lawton L (2009) Business Simulations and Cognitive Learning Developments, Desires, and Future Directions. Simulation \& Gaming 40(2): 193-216.

Arellano F, Hine S and Thilmany DD (2001) Using MANECSIM as a Simulation for Agribusiness Capstone Courses. Review of Agricultural Economics 23(1): 275-285.

Avramenko A (2012) Enhancing students' employability through business simulation. Education + Training 54(5): 355-367.

Behar-Horenstein LS and Niu L (2011) Teaching Critical Thinking Skills In Higher Education: A Review Of The Literature. Journal of College Teaching \& Learning 8(2), Available at: http://journals.cluteonline.com/index.php/TLC/article/view/3554 (accessed 11 April 2014).

Bland JM and Altman DG (1997) Statistics notes: Cronbach's Alpha. British Medical Journal 314: 572.

Cannice MV (2013) The right moves: Creating experiential management learning with chess. The International Journal of Management Education, 11(1), 25-33.

Curry B and Moutinho L (1992) Using computer simulations in management education. Management Learning 23: 155-167.

Dempsey JV, Haynes LL, Lucassen BA, et al. (2002) Forty simple computer games and what they could mean to educators. Simulation \& Gaming 33(2): 157-168.

Dewey J (1933) How We Think. New York: D.C Health \& Co Publishers.

Doyle D and Brown FW (2000) Using a business simulation to teach applied skills - The benefits and the challenges of using student teams from multiple countries. Journal of European Industrial Training 24(6): 330-336.

Ellington H (2004) Higher Education Academy Imaginative Curriculum Guide: Using games, simulations, case studies and role-play to stimulate students' creativity. York, UK, Available at: www.heaacademy.ac.uk/1646.html.

Facione P (1990) The California critical thinking skills test: College level. Millbrae, CA: California Academic Press. 
Facione P, Giancarlo C, Facione N, et al. (1995) The disposition toward critical thinking. Journal of General Education 44(1): 1-25.

Facione P, Facione N and Giancarlo C (2001) California Critical Thinking Disposition Inventory: CCTDI Inventory Manual. Millbrae, CA: California Academic Press.

Faria AJ, Hutchinson D, Wellington WJ, et al. (2009) Developments in business gaming: A review of the past 40 years. Simulation \& Gaming 40(4): 464-487.

Feinstein AH, Mann S and Corsun DL (2002) Charting the experiential territory: Clarifying definitions and uses of computer simulation, games, and role play. Journal of Management Development 21(10): 732744.

Foxall G, Payne A, Taylor J et al. (1990). Marketing vs non-marketing managers. Marketing Intelligence \& Planning 8: 63-66.

Friedel C, Irani T, Rhoades E, et al. (2008) It's in the genes: Exploring relationships between critical thinking and problem solving in undergraduate agri-science students' solutions to problems in Mendelean genetics. Journal of Agricultural Education 49(4): 25-37.

Fripp J (1997) A future for business simulations? Journal of European Industrial Training 21(4): 138-142.

Grimley M, Green R, Nilsen T, et al. (2011) Using computer games for instruction: The student experience. Active Learning in Higher Education 12(1): 45-56.

Guetzkow H (1963) Simulation in International Relations. Englewood Cliffs, NJ: Prentice-Hall.

Halpern DF (1996) Thought and Knowledge: An Introduction to Critical Thinking. Mahwah, NJ: Lawrence Erlbaum.

Halpern DF (1998) Teaching critical thinking for transfer across domains. Dispositions, skills, structure training, and metacognitive monitoring. The American Psychologist 53(4): 449-455.

Huitt W (1998) Critical Thinking: An Overview. Valdosta, GA.: Valdosta State University.

Hutcheson G and Sofroniou N (1999) The Multivariate Social Scientist. London: Sage.

Irani T, Rudd R, Gallo M, et al. (2007) Critical Thinking Instrumentation Manual. Gainesville, FL.: University of Florida.

Ituma, A, 2011. An evaluation of students' perceptions and engagement with e-learning components in a campus based university. Active Learning in Higher Education 12: 57-68. DOI: $10.1177 / 1469787410387722$

Jackson D (2014) Business graduate performance in oral communication skills and strategies for improvement. The International Journal of Management Education, 12(1), 22-34. 
Jehn KA and Mannix EA (2001) The dynamic nature of conflict: A longitudinal study of intragroup conflict and group performance. Academy of Management Journal 44(2): 238-251.

King $M$ and Newman R (2009) Evaluating business simulation software: approach, tools and pedagogy. On the Horizon 17(4): 368-377.

King PM and Kitchener KS (1994) Developing Reflective Judgment: Understanding and Promoting Intellectual Growth and Critical Thinking in Adolescents and Adults. San Francisco: Jossey-Bass.

Kirriemuir J (2002) The relevance of video games and gaming consoles to the higher and further education learning experience. JISC: 3(1). Available at: www.jisc.ac.uk/uploaded_documents/tsw_0201.rtf (accessed 27 January 2014).

Kirton M (1984) Adaptors and innovators: Why new initiatives get blocked. Long Range Planning 17: 137-143.

Kovalik DL and Kovalik LM (2007) Language simulations: The blending space for writing and critical thinking. Simulation \& Gaming 38(3): 310-322.

Lainema T and Nurmi S (2006) Applying an authentic, dynamic learning environment in real world business. Computers \& Education 47(1): 94-115.

Lamm A, Harder A, Irani T, et al. (2011) Developing strong international education programs by understanding cognition. Journal of International Agricultural and Extension Education 18(2): 30-39.

Lean J, Moizer J, Towler M, et al. (2006) Simulations and games: Use and barriers in higher education. Active Learning in Higher Education 7(3): 227-242.

Martin D and McEvoy B (2003) Business simulations: a balanced approach to tourism education. International Journal of Contemporary Hospitality Management, 15(6), 336-339.

Meyers C (1986) Teaching students to think critically. San Francisco: CA: Jossey-Bass.

Mezirow J (1990) Fostering critical reflection in adulthood. San Francisco: CA: Jossey-Bass.

Moizer J, Lean J, Towler M, et al. (2009) Simulations and games Overcoming the barriers to their use in higher education. Active Learning in Higher Education, 10(3), 207-224.

Morgan G (2009) Challenges of Online Game Development: A Review. Simulation \& Gaming 40(5): 688710.

Morris, C and Chikwa, G (2014) Screencasts: How effective are they and how do students engage with them? Active Learning in Higher Education 15: 25-37.

Ogba I, Saul N and Coates, N (2012) Predicting students' attitudes towards advertising on a university Virtual Learning Environment (VLE). Active Learning in Higher Education 13: 63-75. doi:10.1177/1469787411429184. 
Örtenblad A, Koris R, Farquharson M, et al. (2013) Business school output: A conceptualisation of business school graduates. The International Journal of Management Education, 11(2), 85-92.

Piercy N and Caldwell N (2011) Experiential learning in the international classroom: Supporting learning effectiveness and integration. The International Journal of Management Education, 9(2), 25-35.

Platzer H, Snelling J and Blake D (1997) Promoting reflective practitioners in nursing: A review of theoretical models and research into the use of diaries and journals to facilitate reflection. Teaching in Higher Education 2(2): 103-121.

Pryjmachuk S, Gill A, Wood P, et al. (2012) Evaluation of an online study skills course. Active Learning in Higher Education 13(2): 155-168

Rhem J (1998) Problem-based learning: An introduction. The National Teaching \& Learning Forum 8(1): $1-4$.

Ricketts JC and Rudd RR (2004) The relationship between critical thinking dispositions and critical thinking skills of selected youth leaders in the national FFA organization. Journal of Southern Agricultural Education Research, 54(1): 21-33.

Roth MS (2010) Beyond critical thinking. The Chronicle of Higher Education, January 3rd, Available at: https://chronicle.com/article/Beyond-Critical-Thinking/63288/ (accessed 12 March 2014).

Sekaran U (2003) Research Methods for Business: A Skill Building Approach. New York: Johan Wiley \& Sons.

Snyder KD (2003) Ropes, poles, and space: Active learning in business education. Active Learning in Higher Education 4(2): 159-167.

Springer CW and Borthick AF (2004) Business simulations to stage critical thinking in introductory accounting: Rationale, design, and implementation. Issues in Accounting Education 19(3): 277-303.

Stassen MLA, Herrington A and Henderson L (2011) Defining critical thinking in higher education. In: To Improve the Academy: Resources for Faculty, Instructional, and Organizational Development. San Francisco: Jossey-Bass, pp. 126-141.

Stedman NL and Andenoro C (2007) Identification of relationships between emotional intelligence and critical thinking dispositions in undergraduate leadership students. Journal of Leadership Education 6(1): 190-208.

Sutcliffe M (2002) Games, Simulations and Role Playing: The Handbook for Economics Lecturers. Bristol, UK: Economics LTSN.

Taggart W, Robey D and Kroeck C (1985) Managerial decision styles and cerebral dominance: An empirical study. Journal of Management Studies 22(2): 175-192. 
Tishman S and Andrade A (1996) Thinking dispositions: A review of current theories, practices, and issues. Cambridge, Marvard University, Available at: http://learnweb.harvard.edu/alps/thinking/docs/Dispositions.pdf (accessed 12 December 2013).

Tishman S, Jay E and Perkins DN (1993) Teaching thinking dispositions: From transmission to enculturation. Theory Into Practice 32(3): 147-153.

Tiwari SR, Nafees L and Krishnan O (2014) Simulation as a pedagogical tool: Measurement of impact on perceived effective learning. The International Journal of Management Education, 12(3), 260-270.

Whiteley TR and Faria AJ (1989) A study of the relationship between student final exam performance and simulation game participation. Simulation \& Gaming 20(1): 44-64.

Witkin HA, Moore CA, Oltman PK, Goodenough DR, et al. (1977) Role of the field dependent and field independent cognitive styles in academic evolution: A longitudinal study. Journal of Educational Psychology 69(3): 197-211. 